SEJ (School Education Journal)

Vol. 11 No. 3 Desember 2021

\title{
PENGEMBANGAN MEDIA “SMART BOARDBOOK” BERBASIS AUGMENTED REALITY PADA TEMA 6 SUBTEMA 1 KELAS II SD NEGERI 104197 DESA KLAMBIR
}

\author{
Nurmayani, Liza Ayu Khairani \\ Surel: nurmayani111161@gmail.com
}

\begin{abstract}
The purpose of this study was to determine the feasibility and effectiveness of using Augmented Reality-based "Smart Boardbook" media. This research is a development research (Research and Development) which refers to the ADDIE development model which consists of 5 stages, namely the analysis, design, development, implementation, and evaluation stages. The research shows that the augmented reality-based "smart boardbook" media on the theme of 6 sub-theme 1 class II SD that was developed has been validated by a media expert validator in the first stage obtaining a feasibility percentage of $73.80 \%$ included in the "feasible" criteria and in stage II obtaining the results of the percentage of eligibility of $95.20 \%$ are included in the "very feasible" criteria. And according to the material expert validator in stage I the percentage of feasibility results is $75.55 \%$. included in the "feasible" criteria and in stage II the percentage of eligibility results was $92.22 \%$. included in the "very feasible" criteria. And according to education practitioners, the percentage of eligibility results is $98.18 \%$ including the "very feasible" criteria. The results of individual trials and small group trials each get an average score of 1 which is in the "good" category. In the field trial stage, the effectiveness criteria were achieved with the number of students reaching 17 people in the post-test or about $89.47 \%$.
\end{abstract}

Keywords: Augmented Reality, Media, Research Development, Smart Boardbook

\begin{abstract}
ABSTRAK
Tujuan penelitian ini adalah untuk mengetahui kelayakan dan keefektifan penggunaan media "Smart Boardbook" berbasis Augmented Reality. Penelitian ini merupakan penelitian pengembangan (Research and Development) yang mengacu pada model pengembangan ADDIE yang terdiri dari 5 tahapan yaitu tahap analysis (analisis), design (desain), development (pengembangan), implementation (implementasi), dan evaluation (evaluasi). Hasil penelitian menunjukkan bahwa media "smart boardbook" berbasis augmented reality pada tema 6 subtema 1 kelas II SD yang dikembangkan telah divalidasi oleh validator ahli media pada tahap I memperoleh hasil persentase kelayakan sebesar 73,80\% termasuk dalam kriteria "layak" dan pada tahap II memperoleh hasil persentase kelayakan sebesar 95,20\% termasuk dalam kriteria "sangat layak". Serta menurut validator ahli materi pada tahap I hasil persentase kelayakan sebesar $75,55 \%$. termasuk dalam kriteria "layak" dan pada tahap II memperoleh hasil persentase kelayakan sebesar 92,22\%. termasuk dalam kriteria "sangat layak". Serta menurut praktisi pendidikan memperoleh hasil persentase kelayakan sebesar 98,18\% termasuk kriteria "sangat layak". Hasil uji coba perorangan dan uji coba kelompok kecil masing-masing mendapatkan skor rata-rata 1 yakni berada pada kategori "baik". Pada tahap uji coba lapangan kriteria keefektifan tercapai dengan jumlah siswa yang mencapai 17 orang pada post-test atau sekitar $89,47 \%$.
\end{abstract}

Kata Kunci : Augmented Reality, Media, Penelitian Pengembangan, Smart Boardbook 



\section{PENDAHULUAN}

Perkembangan ilmu pengetahuan, teknologi informasi dan komunikasi memberikan dampak yang signifikan dalam beberapa aspek kehidupan masyarakat. Salah satunya dalam aspek pendidikan. Dengan teknologi, dunia pendidikan bisa memberikan warna baru dalam proses pembelajaran yaitu dengan mengembangkan media berbasis teknologi. Hal ini mendorong manusia untuk semakin kreatif dalam mengelola ilmu pengetahuan sehingga mampu merubah pola pikir manusia untuk dapat berfikir secara efektif dan efisien agar tidak tertinggal dalam perkembangan di dunia teknologi informasi dan komunikasi.

Pendidikan harus mampu menyelaraskan kebutuhan anak didik dengan perkembangan zaman yang senantiasa mengalami perubahan.Maka dari itu untuk mengatasi hal tersebut penggunaan media sebagai alat bantu mengajar sangat diperlukan. Terkhusus pada perkembangan zaman yang menerapkan media pembelajaran dengan bantuan teknologi.

Media pembelajaran merupakan komponen instruksional yang meliputi pesan, orang, dan peralatan. Menurut Rusman (2013) menyatakan bahwa media Pembelajaran merupakan suatu teknologi pembawa pesan yang dapat digunakan untuk keperluan pembelajaran dan sarana fisik untuk menyampaikan materi pelajaran. Dalam perkembangannya media pembelajaran mengikuti perkembangan teknologi. Media pembelajaran harus dikembangkan sesuai dengan kebutuhan dan kondisi siswa karena kebutuhan siswa tidak akan selalu sama serta mengalami perkembangan sesuai dengan perkembangan ilmu dan teknologi seperti sekarang ini.

Saat ini di sekolah dasar melaksanakan pembelajaran tematik yang membutuhkan media pembelajaran dalam pelaksanaannya. Kehadiran media pembelajaran memiliki arti penting bagi guru maupun siswa selama pembelajaran berlangsung. Proses pembelajaran yang masih menggunakan metode ceramah dan tidak memberikan contoh-contoh melalui media berbentuk konkret akan sulit diterapkan pada anak sekolah dasar khususnya siswa di kelas rendah seperti kelas I, II, dan III. Siswa di kelas rendah lebih tertarik dengan pembelajaran yang menggunakan media pembelajaran untuk menumbuhkan motivasi belajar. Penggunaan media yang menarik dan berbentuk konkret dapat menjadi pilihan bagi guru dalam menyampaikan materi pembelajaran. Media konkret juga dapat di gunakan bersamaan dengan teknologi yang mampu menciptakan suasana yang menyenangkan dan antusias siswa dalam belajar terbentuk.

Media Pembelajaran dapat berupa gambar, audio, video, serta animasi dan multimedia. Penerapan media pembelajaran dalam bentuk multimedia merupakan suatu hal penting karena salah satunya dipakai sebagai alat pembelajaran pada dunia 
Nurmayani, Liza Ayu Khairani : Pengembangan Media ....

pendidikan. Salah Satu media pembelajaran dalam bentuk multimedia yaitu dengan berbasis Augmented Reality (AR). Media pembelajaran yang dapat menciptakan refleksi gambar dua dimensi menjadi tiga dimensi. Media dengan bantuan AR ini mampu merealisasikan dunia virtual ke dunia nyata, sehingga siswa mendapatkan visualisasi yang jelas dan lebih realistis terhadap materi dan dapat dengan mudah memahami materi yang disampaikan. Hal ini sejalan dengan pendapat Ismayani (2020) menyatakan bahwa AR adalah sebuah teknologi yang menggabungkan objek buatan komputer, dua dimensi atau tiga dimensi, ke dalam lingkungan nyata di sekitar penggunaan secara real time.

Augmented reality merupakan penggabungan antara objek virtual dengan objek nyata. Augmented reality biasa disingkat dengan teknologi AR. Teknologi ini merupakan sebuah terobosan terobosan dan inovasi di bidang multimedia dan sudah banyak digunakan sebagai alat bantu pembelajara. Permasalahan dalam penggunaan media pembelajaran biasanya terjadi karena media yang digunakan sebagai alat bantu pembelajaran itu kurang menarik bagi siswa serta tidak memberikan pemahaman materi yang baik bagi siswa. Tetapi dengan bantuan teknologi augmented reality, proses pembelajaran khususnya dalam pengenalan sebuah konsep atau materi bagi siswa akan menjadi mudah di sampaikan.

Penggunaan aplikasi augmented reality tidak bisa digunakan apabila tidak ada perangkat keras seperti kartu atau buku dalam pengoperasiannya. Inovasi yang di berikan dapat berupa sebuah buku yang tahan lama tidak mudah sobek dan kotor apabila digunakan kepada siswa sekolah dasar. Buku ini bernama "smart boardbook",media berbentuk buku ini menurut Hanung (2018) menyatakan bahwa buku dengan sampul dan halaman-halaman yang terdiri atas kertas berbahan kaku, keras, dan lebih tebal dari halaman kertas pada umumnya.Media ini akan memberikan pengalaman belajar yang lebih menarik karena berbeda dari buku pegangan di sekolah. Sekolah dasar yang di dominasi dengan karakter siswa yang suka bermain dan lebih menyukai halhal yang menarik dan menyenangkan. Guru harus bisa menyesuaikan hal tersebut untuk di padukan kedalam proses belajar mengajar.

Berdasarkan hasil observasi langsung dan wawancara yang dilakukan di SD Negeri 104197 Desa Klambir pada tanggal 1 oktober 2020, dengan berfokus pada 32 siswa kelas II. Keadaan proses pembelajaran saat melakukan observasi. Proses pembelajarannya terlihat guru berfokus pada buku dan menjelaskan dengan sistem ceramah, serta kurangnya media pendukung dalam pembelajaran membuat siswa sulit belajar dengan fokus. Antusias siswa menjadi tidak terlihat karena proses 
pembelajaran yang diciptakan guru juga kurang memberikan kesan menyenangkan dan terlihat monoton. Siswa tidak terlalu mempehatikan materi pembelajaran dibuku karena merasa gambar yang ada dibuku tidak menarik. Hal itu membuat pemahaman siswa terhadap materi juga rendah. Para siswa lebih menyukai dan tertarik terhadap media pembelajaran yang berisi gambargambar karena dapat menarik perhatian dan mempermudah siswa dalam belajar serta memberikan gambaran yang lebih jelas tentang materi yang dipelajari.

Hasil observasi awal yang dilakukan peneliti di SDN 104197 Desa Klambir, diperoleh data nilai harian tema 2 subtema 1 dengan fokus pelajaran Bahasa Indonesia, SBdP, dan Matematika siswa kelas IIA, masih dalam kategori rendah dan banyak siswa yang tidak tuntas. Dari nilai harian siswa yang berjumlah 32 orang pada 3 mata pelajaran yang masing-masing memiliki persentase belum tuntas lebih besar dari pada yang tuntas. Hal ini menunjukkan siswa masih belum memenuhi pencapaian Kriteria Ketuntasan Minimum (KKM). Data persentase nilai bahasa indonesia yang belum tuntas sebesar 56,25\%, SBdp sebesar $53,12 \%$, dan Matematika sebesar $56,25 \%$ menunjukkan persentase angka yang lebih besar dari pada siswa yang tuntas. Proses pembelajaran seharusnya dapat memberikan pemahaman yang baik agar pencapaian semua siswa dapat memenuhi kriteria dengan cara menciptkan pembelajaran yang bermakna dan menyenangkan.

Berdasarkan dari permasalahan yang telah dipaparkan diatas serta rendahnya hasil nilai siswa kelas II-A agar guru harus bisa menciptkan inovasi baru baik berupa metode dan penggunaan media pembelajaran bagi siswa. Maka dapat di simpulkan solusi yang dapat diberikan adalah dengan mengembangkan sebuah media pembelajaran berbasis Augmented Reality dengan nama "Smart Boardbook" yang berbentuk seperti buku dengan halaman yang terdiri atas kertas berbahan kaku, keras dan lebih tebal serta akan diisi dengan gambar dua dimensi yang dapat di scan melalui smartphone dengan menggunakan bantuan AR (Augmented Reality) agar menciptakan kesan bertiga dimensi untuk menarik minat dan antusias siswa kelas rendah.

\section{METODE PENELITIAN}

Penelitian ini menggunakan pendekatan penelitian dan pengembangan atau Research and Development (R\&D). Sugiyono (2017) menjelaskan bahwa metode penelitian dan pengembangan (R\&D) adalah metode penelitian yang digunakan untuk menghasilkan rancangan produk baru, menguji keefektifan produk yang telah ada, serta mengembangkan dan menciptakan produk baru. Semua produk teknologi diproduksi dan dikembangkan melalui penelitian dan pengembangan. Desain pengembangan dalam penelitian ini 
Nurmayani, Liza Ayu Khairani : Pengembangan Media ....

menggunakan model Analysis, DesignDevelopment, Implementation, Evaluation (ADDIE) oleh Robert Maribe Brach. Sesuai dengan namanya, model ADDIE terdiri dari lima tahapan yaitu analisis, desain, pengembangan, implementasi, dan evaluasi. Penelitian pengembangan ini berorientasi pada pengembangan produk dimana proses pengembangannya dideskripsikan seteliti mungkin.

Subjek dalam penelitian ini adalah siswa kelas II-A semester genap tahun ajaran 2020/2021 di SD Negeri 104197 Desa Klambir yang berjumlah 32 orang. Siswa laki-laki berjumlah 18 orang dan siswa perempuan berjumlah 14 orang. Produk yang dihasilkan akan di uji dengan uji coba perorangan, uji coba kelompok kecil dan uji coba lapangan. Pengujian ini dilakukan untuk mengetahui respon dan pemahaman siswa kelas II-A SD Negeri 104197 Desa klambir terhadap media yang dikembangkan.

Jenis data yang diperoleh dari penelitian dan pengembanan ini adalah data deskriptif kualitatif dan kuantitatif. Deskriptif kualitatif diperoleh dari komentar ahli materi, ahli media, praktisi pendidikan (guru kelas) dan angket respon siswa tentang produk yang dikembangkan. Data deskriptif kuantitatif diperoleh dari skor penilaian ahli materi, ahli media, praktisi pendidikan (guru kelas) dan angket respon siswa serta penilaian dari lembar pretest dan posttest siswa.
Pengumpulan data dalam penelitian pengembangan ini menggunakan instrument lembar angket validasi, angket respon siswa dan lembar pretest dan posttes. Lembar angket validasi digunakan untuk memvalidasi dan mengetahui kualitas kelayakan produk yang dikembangkan.Uji Kelayakan produk dilakukan oleh ahli yang berkompeten dalam hal produk yang dikembangkan dalam hal ini sebagai validator yaitu ahli materi dan ahli media serta praktisi pendidikan.

Angket respon siswa dilakukan pada saat uji coba perorangan dan kelompok kecil. Hal ini dilakukan untuk mengetahui respon siswa terhadap media pembelajaran yang dikembangkan. Lembar angket respon siswa digunakan untuk memperoleh data tentang kelayakan media yang dikembangkan. Lembar pretest dan posttest digunakan untuk mengethaui hasil belajar siswa kelas II SD Negeri 104197 Desa Klambir sebelum dan sesudah menggunakan media yang telah dikembangkan. Analisis data yang dilakukan meliputi analisis data kelayakan (ahli media, ahli materi, praktisi pendidikan), data respon siswa dan data hasil belajar siswa. Data kelayakan media akan di analisis menggunakan skala likert dengan skor 1 sampai 5. Data angket yang telah di isi oleh validator berikutnya akan dilakukan analisis dan persentase menurut Sugiyono dengan menggunakan skala Likert sebagai berikut: 
Tabel 1. Kriteria Pedoman Penentuan Skoring Skala Likert

\begin{tabular}{c|c|c}
\hline No. & Kriteria & Skor \\
\hline 1. & Sangat Layak & 5 \\
\hline 2. & Layak & 4 \\
\hline 3. & Cukup Layak & 3 \\
\hline 4. & Kurang Layak & 2 \\
\hline 5. & Tidak Layak & 1 \\
\hline \multicolumn{2}{c}{ (Sugiyono, 2014) }
\end{tabular}

Tabel 2. Persentase Ketercapaian Media

\begin{tabular}{c|c|c|c}
\hline No. & $\begin{array}{c}\text { Tingkat } \\
\text { Pencapaian \% }\end{array}$ & Kualifikasi & Keterangan \\
\hline 1. & $81-100$ & Sangat layak & Tidak perlu revisi/valid \\
\hline 2. & $61-80$ & Layak & Tidak perlu revisi/valid \\
\hline 3. & $41-60$ & Cukup layak & Revisi/tidak valid \\
\hline 4. & $21-40$ & Kurang layak & Revisi/tidak valid \\
\hline 5. & $0-20$ & Tidak layak & Revisi/tidak valid \\
\hline
\end{tabular}

(St Muriati, 2013)

Tahap uji coba terbatas yang akan dilakukan yaitu uji coba per orangan dan uji coba kelompok kecil. Angket yang digunakan pada tahap uji coba ini yaitu skala Guttman, data angket respon siswa yang didapatkan pada uji coba yaitu mengenai penilaian siswa terhadap media "smart boardbook" berbasis augmented reality setelah mereka menggunakannya. Skoring pada angket respon siswa yaitu skor 1 untuk jawaban "ya" dan skor 0 untuk jawaban "tidak".

Analisis data hasil pre-test dan post-test yang sudah diujikan pada uji coba lapangan di hitung untuk menentukan persentase ketuntasan belajar siswa.
Berdasarkan dengan konsep belajar tuntas, Nurhayati (2016) menyatakan bahwa suatu kelas dikatakan tuntas secara klasikal jika $85 \%$ atau lebih siswa yang tuntas belajar. Ketuntasan kelas dapat dihitung dengan menggunakan rumus sebagai berikut:

Persentase daya tuntas klasikal $=\frac{\text { Banyaknya siswa yang tuntas }}{\text { Banyak siswa keseluruhan }} \times 100 \%$ Indikator keberhasilan penilaian adalah ketuntasan klasikal rata-rata $85 \%$.

\section{HASIL PENELITIAN DAN PEMBAHASAN}

Penelitian ini menghasilkan produk berupa media pembelajaran yang menjelaskan materi tematik pada tema 6 subtema 1 pembelajaran 
Nurmayani, Liza Ayu Khairani : Pengembangan Media ....

1 dengan bentuk sebuah buku yang berisikan marker yang akan menghasilkan bentuk 3 dimensi bila digunakan bersama dengan aplikasi augmented reality, yang dikemas dalam media smart boardbook berbasis augmented reality. Pengembangan media ini menggunakan langkah-langkah dalam penelitian pengembangan model ADDIE, dengan tahapan Analysis (Analisis), Design (Desain), Development (Pengembangan), Implementation (Implementasi), dan Evaluation (Evaluasi).Proses analisis dilakukan melalui observasi dan wawancara di SD Negeri 104197 Desa Klambir untuk mengetahui permasalahan yang terjadi pada proses pembelajaran yang dilakukan oleh guru dan siswa, sehingga akan diberikannya solusi terkait permasalahan tersebut. Proses desain media smart boardbook berbasis augmented reality, perlu adanya desain sketsa yang digunakan untuk menggambarkan pembuatan media. Desain produk media smart boardbook berbasis augmented reality yang dikembangkan dalam penelitian ini menggunakan bantuan Microsoft word 2010, File desain buku kemudian dibawa ke percetakan untuk diproduksi menjadi buku yang sesuai dengan hasil yang baik. Aplikasi Augmented Realitydibuat dengan bantuan programmer yang ahli dalam mengoperasikan komputer sehingga menghasilkan bentuk media sebagai berikut:

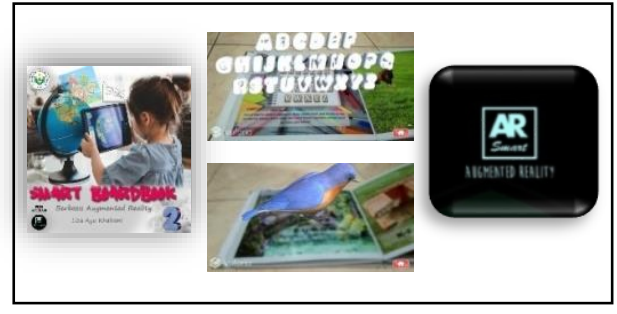

Gambar 1. Media smart boardbook berbasis augmented reality

Produk yang telah dibuat kemudian divalidasi oleh validator ahli media, ahli materi, dan praktisi pendidikan (guru kelas). Hasil penilaian validasi dari ahli media diperoleh dengan nilai persentase kelayakan $\quad 73,80 \% \quad$ sebelum dilakukannya revisi. Media di perbaiki sesuai dengan saran dan komentar dari ahli media sehingga setelah direvisi diperoleh hasil persentase kelayakan sebesar 95,20\%. Perolehan persentase tersebut menunjukkan bahwa media smart boardbook berbasis augmented realityyang dikembangkan mendapatkan kriteria sangat layak. Diagram di bawah ini merupakan hasil penilaian dari ahli media pada tahap I (sebelum revisi) dan Tahap II (sesudah revisi).

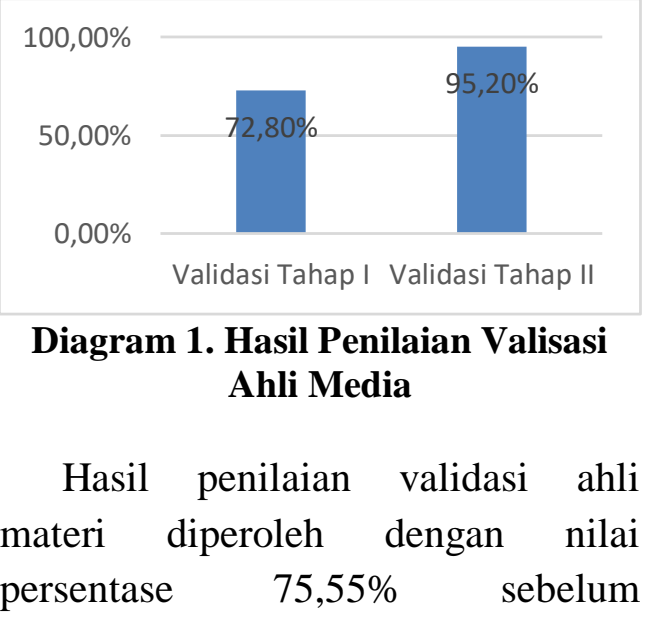


dilakukannya revisi. Media diperbaiki sesuai dengan saran dan komentar dari ahli materi sehingga setelah direvisi diperoleh hasil persentase kelayakan sebesar $92,22 \%$. Perolehan persentase tersebut menunjukkan bahwa media smart boardbook berbasis augmented realityyang dikembangkan mendapatkan kriteria sangat layak. Diagram di bawah ini merupakan hasil penilaian dari ahli materi pada tahap I (sebelum revisi) dan Tahap II (sesudah revisi).

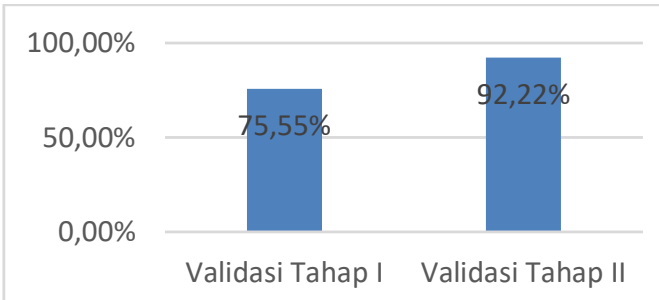

Diagram 2. Hasil Penilaian Validasi Ahli Materi

Penilaian praktisi pendidikan oleh guru kelas II-A SD Negeri 104197 Desa Klambir memperoleh hasil persentase kelayakan sebesar $98,18 \%$. Perolehan persentase tersebut menunjukkan bahwa media smart boardbook berbasis augmented reality yang dikembangkan mendapatkan kriteria sangat layak.

Kelayakan media pembelajaran dapat dilihat dari respon siswa terhadap penggunaan media selama proses pembelajaran berlangsung. Oleh karena itu peneliti membagikan angket respon siswa terhadap media pada uji coba perorangan dan uji coba kelompok kecil untuk melihat respon siswa terhadap media smart boardbook berbasis augmented reality. Dari hasil uji coba perorangan yang dilakukan pada 3 orang siswa kelas II-A SD Negeri 104197 Desa Klambir yaitu mendapatkan skor ratarata 1 yakni berada pada kategori "baik".

Hasil uji coba kelompok kecil yang dilakukan pada 10 orang siswa, mendapatkan skor rata-rata 1 yakni berada pada kategori "baik". Hal ini bermakna bahwa media smart boardbook berbasis augmented reality mendapat predikat penilaian dengan nilai baik sebagai media pembelajaran dalam proses belajar secara individual maupun berkelompok.

Keefektifan

media

pembelajaran smart boardbook berbasis augmented reality di ketahui melalui uji coba produk, uji coba produk yang dilakukan yaitu uji coba lapangan. Pada tahap ini peneliti mengukur keefektifan penggunaan media smart boardbook berbasis augmented reality dalam pembelajaran menggunakan tes hasil belajar. Sebelum dilakukan uji coba produk, peneliti melakukan pre-test kepada siswa untuk menguji tingkatan pengetahuan siswa terhadap materi yang akan disampaikan.

Selanjutnya pada uji coba produk, kegiatan pembelajaran dilakukan seperti kegiatan pembelajaran sehari-hari dengan acuan RPP yang akan dibawakan langsung oleh guru kelas. Dalam menjelaskan materi guru akan menggunakan media pembelajaran sebagai alat pendukung pembelajaran. Setelah selesai menggunakan media smart boardbook berbasis augmented reality, siswa dibagikan post-test 
untuk melihat hasil belajar setelah menggunakan media pembelajaran.

Berdasarkan uji coba lapangan yang telah dilakukan maka kriteria keefektifan tercapai dengan jumlah siswa yang mencapai 17 orang pada post-test atau sekitar $89,47 \%$ kategori sangat baik. Kriteria keefektifan terpenuhi atau dikatakan baik jika siswa yang mencapai ketuntasan lebih besar atau sama dengan $85 \%$. Maka tingkat keefektifan mediatermasuk dalam kategori efektif digunakan dalam proses pembelajaran.Berikut ini adalah data hasil ketuntasan hasil belajar siswa lebih jelasnya dapat dilihat pada tabel dibawah ini:

Tabel 3. Ketuntasan Hasil Belajar Siswa Pada Uji Coba Lapangan

\begin{tabular}{c|c|c|c|c|c}
\hline \multirow{2}{*}{ Nilai } & \multirow{2}{*}{ Kategori } & \multicolumn{2}{|c|}{ Pre-test } & \multicolumn{2}{c}{ Post-test } \\
\cline { 3 - 6 } & Frekuensi & Persentase & Frekuensi & Persentase \\
\hline $\begin{array}{c}70- \\
100\end{array}$ & Tuntas & 13 & $68,42 \%$ & 17 & $89,47 \%$ \\
\hline $\begin{array}{c}0- \\
69\end{array}$ & $\begin{array}{c}\text { Tidak } \\
\text { Tuntas }\end{array}$ & 6 & $31,57 \%$ & 2 & $10,52 \%$ \\
\hline
\end{tabular}

Persentase rata-rata hasil belajar siswa pada uji coba lapangan dapat dilihat pada diagram dibawah ini:

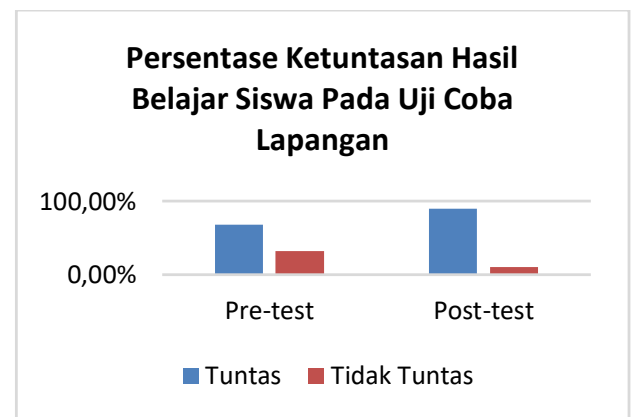

Diagram 3. Persentase Ketuntasan Hasil Belajar Siswa Pada Uji Coba Lapangan

\section{Pembahasan}

Uraian diatas dapat disimpulkan bahwa media smart boardbook berbasis augmented reality yang dikembangkan secara umum sudah baik dan layak digunakan, namun ada beberapa hal yang perlu direvisi seperti menyesuaikan icon/ tombolpada aplikasi serta penjilidan buku yang mudah digunakan. Respon siswa terhadap media smart boardbook berbasis augmented reality secara keseluruhan memperoleh respon yang baik dimana menurut siswa media yang dikembangkan sangat menarik, mudah digunakan, serta gambar dan suara yang jelas.

Proses menilai hasil belajar siswa terhadap produk di uji cobakan dengan lembar pre-post test. Saat uji coba lapangan ini guru dan siswa bersama-sama untuk mengikuti pembelajaran dengan menggunakan media smart boardbook berbasis augmented reality dengan acuan pembelajaran berpedoman pada RPP. Dari hasil uji coba lapangan memperoleh hasil akhir dengan hasil belajar siswa meningkat dan tingkat keefektifan media termasuk kedalam kategori sangat baik.

\section{SIMPULAN}

Berdasarkan hasil hasil penelitian dan pengembangan yang telah dilakukan dapat diambil kesimpulan sebagai berikut: Media smart boardbook berbasis augmented realityberbentuk buku berbahan kertas karton tebal berisikan marker yang digunakan bersamaan dengan aplikasi augmented realitydengan 
nama SmartAR. Kelayakan mediasmart boardbook berbasis augmented reality diukur dengan kegiatan validasi oleh ahli media, ahli materi dan praktisi pendidikan, dari hasil penilaian oleh ahli media diperoleh rerata sebesar $95,20 \%$ kategori sangat layak, ahli materi diperoleh rerata sebesar $92,22 \%$ kategori sangat layak, dan praktisi pendidikan diperoleh rerata sebesar 98,18\% kategori sangat layak. Selanjutnya diukur melalui angket respon siswa dengan uji coba perorangan dan uji coba kelompok kecil yaitu masing-masing mendapatkan skor rata-rata 1 kategori baik. Keefektifan media smart boardbook berbasis augmented reality di ukur melalui instrumen tes hasil belajar dengan uji coba lapangan diperoleh rerata sebesar $89,47 \%$ kategori sangat baik sehingga berdasarkan rerata hasil belajar siswa tersebut.

\section{DAFTAR RUJUKAN}

Arikunto, S. 2013. Dasar-Dasar Evaluasi Pendidikan (edisi 2). Jakarta: Bumi Aksara.

Arsyad, A. 2020. Media Pembelajaran. Jakarta: Rajawali Pers.

Ismayani, A. 2020. Membuat Sendiri Aplikasi Augmented Reality. Jakarta: Elex Media Komputindo.

Latip, A. E. 2018. Evaluasi Pembelajaran Di SD Dan MI Perencanaan dan Pelaksanaan Penilaian Hasil Belajar Autentik. Bandung: Remaja Rosdakarya.
Munir. 2017. Pembelajaran Digital. Bandung: Alfabeta

Muriati, St. 2014. Pengembangan Bahan Ajar Biologi Sel Pada Program Studi Pendidikan Biologi UN Alauddin Makassar. Jurnal Florea, 1 (2), h. 14-20.

Mustaqim, I. dan Nanang K. 2017. Pengembangan Media Pembelajaran Berbasis Augmented Reality. Jurnal Edukasi, 1 (1), 3648.

Nurhayati. 2016. Meningkatkan Hasil Belajar Siswa Dengan Menggunakan Metode Bimbingan Mata Pelajaran IPA di Kelas III SD Impres 1 Bainaa. Jurnal Kreatif Tadulako Online, 4 (10), h. 1-11.

Nuritta, T. 2018. Pengembangan Media Pembelajaran Untuk Meningkatkan Hasil Belajar Siswa. Misykat, 3 (1), h. 171-187.

Rusdi. 2018. Penelitian Desain dan Pengembangan Kependidikan: Konsep, Prosedur dan Sintesis Pengetahuan Baru. Depok: Rajawali Pers.

Saputri, E. F. dkk. 2018. Pengembangan Media Pembelajaran IPA Menggunakan Augmented Reality (AR) Berbasis Android Pada Siswa Kelas III SDN 015 Tarakan. Widyagogik, 6 (1), 57-72.

Sudjana. N. 2016. Penilaian Hasil Proses Belajar Mengajar. Bandung: Remaja Rosdakarya.

Sugiyono. 2017. Metode Penelitian Dan Pengembangan (Research and Development/ $R \& D)$. Bandung: Alfabeta. 